\title{
The Influence of Employee Competency in Small and Medium Business Brazil and Brics and Jair Bolsonaro's 1st Year of Presidency
}

\author{
Vasil Timerjanovich Sakaev ${ }^{*}$ and Tanya Yordanova Popova
}

Institute of International Relations, Kazan Federal University, Kazan, Russia

\begin{abstract}
This study aims to look at employee competency with job satisfaction as an intervening variable at small and medium business (SMB) by consdring the Brazil politics. The political stage in Brazil changed course towards the "right" on 1 January 2019 when the anti-globalist former army officer Jair Bolsonaro was inaugurated as the 38th President of the Republic. That was an abrupt change of ideologies for a country leaded by the "left" (Workers' Party) in the last 13 years. Scholars made contradictory assumptions about the future of BRICS: one of the most significant economic organisations on the international arena nowadays, within the new Brazilian background. In the beginning of 2019 the opportunity for Braxit was not excluded, although there was no immediate call for it. However, the most common opinion came from pragmatists like $\mathrm{N}$. Muhandiram: they affirmed that the union would keep functioning but it would meet multiple challenges. This article gives an answer to the question why the "right" turn in Brazil affects the relations between the biggest Latin American democracy and BRICS.
\end{abstract}

Keywords: Employee's, Brazil, Presidential elections 2018, Jair Bolsonaro, Far right, Foreign policy, BRICS.

\section{INTRODUCTION}

The rapid development, due to the growing global competition, and the advancing technology today requires a company to have a competitive advantage. An advantage can be obtained if the company has competent human resources (Ali et al., 2013). This article exposes the relationship between Brazil and BRICS, since the rising to power of a far right candidate in the beginning of 2019. It reveals the change of dynamics in the 1st year of Bolsonaro's presidency and its influence on the economic union.

For a continental power like Brazil its membership in international organizations is crucial for its economic development, as well as its growth in other spheres, some of which being security, technology, science and innovation. Brazil's participation in BRICS has been a major aspect on the agendas of the previous governments with left orientation. However, the election on 28 October 2018 put an end to an era in the ruling of the Workers' Party (PT), which was in power for 13 years (2003-2016), and it brought to power an ideology, which quite differs from the one, followed up until this moment. That shift opened the way for changes in the framework under which BRICS works. The hypothesis in this paper is that Brazil remains in the union but it is not fully committed to its goals. Its validity is tested through a method called process tracing. It was chosen, as it is the most suitable for an

*Address correspondence to this author at the Institute of International Relations, Kazan Federal University, Kazan, Russia; Tel: +79272493705; E-mail: vasil.sakaev@gmail.com

E-ISSN: 1929-4409/21 observation on a political phenomenon which has happened recently and which is believed to provoke significant changes.

\section{METHODS}

The method that authors rely on is process tracing, which falls under the category of qualitative research. Essentially, this is "the systematic examination of diagnostic evidence selected and analyzed in light of research questions and hypotheses posed by the investigator" (Collier, 2011, Escher, 2020). Description is a fundamental component of this method, as it carefully disseminates the processes of "change" and "causation" in the studied phenomenon. Therefore, it is important to be able to follow the unfolding of events in both situations: over time and at one point in time. This allows the researcher to mark the key steps in the process, which are the essential evidence on which the outcome is based (Beach, 2012).

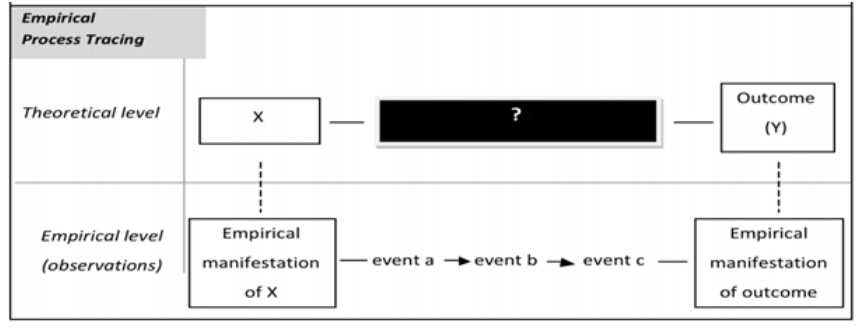

Figure 1: Process Tracing methods.

\section{RESULTS AND DISCUSSIONS}

The relatively young Social Liberal Party (PSL), represented by Bolsonaro, has raised to become "the 
second largest bloc after the Workers' Party" (Gallego, 2018). It has largely demonised the PT (also known as "antipetismo") as a corrupt affiliation which provoked the economic crisis in the country, while its supporters were portrayed as people who only receive benefits from the state but do not work in return (Solano, 2018).

Hunter and Power (2019) explain the glooming success of Jair Bolsonaro as a direct result of four simultaneous crises happening in Brazil: corruption, recession, polarization and rising crime. The former captain seized the moment and managed to successfully position himself as the politician who would fight hard against all these crises and who would be the one to bring the change needed in the country. Economy recession and corruption scandals in the past few years, in particular, have left a deep scar on society's memory and Bolsonaro has used this to get a favourable view for himself: trying to show himself as an authentic leader who will fight to eradicate corruption and build a new economy with open markets.

Leading its beginning from the 2000s and eventually finishing its formation in 2010 when South Africa joined, BRICS nowadays comprises an enormous economic might, due to the large populations of the participating countries and their rich possession of natural resources. Some of the specifics of the group include its non-block character, its principle to stand for neutrality when it comes to third parties and its reliance on multi-actor cooperative nature, with no regards to the fact that geographical proximity does not exist. Scholars have even suggested that BRICS has become an alternative model for world order by employing principles "which exclude mandate, discrimination and hierarchy" (Sergunin and Gao, 2018). Annual summits regulate the work of BRICS and the last one, 11th on the roll, happened in Brazil on November 13-14, 2019 (Mengije, 2018).

The progress reached by BRICS for its first 10 years of existence can be outlined by the following achievements: the NDB (The New Development Bank) was set up; a big step forward to the financial integration of all BRICS' members was done; a trade expansion was rated by $94 \%$ over the course of these 10 years. Furthermore, BRICS has not limited itself to merely an economic union; it proved to be an efficient tool when it comes to global governance, as well. The regular discussions of international political issues and the openness for dialogue with all the developing countries have shaped the vision of BRICS as an open, friendly and cooperative organization. What is more, some economists believe that BRICS is a driving force working towards reducing income inequality and specifically taking into consideration Brazil: "the overall lot of the South has improved dramatically" (Hammond, 2018). Bearing in mind all of this, a participation in BRICS might be an important factor in reaching Bolsonaro's goal "to put Brazil among the world's 50 best countries to do business" with (Presidency of the Republic of Brazil, 2019).

In the process of researching the possible outcomes in the Brazil-BRICS cooperation, there have emerged 3 paths of development that might take tolls. They are summarized below and are numerated from the most probable to the least probable:

1) Brazil staying in the union but not playing an active part in its undertakings: according to Popova, this is the most probable case scenario for the unfolding of the relationship Brazil-BRICS in 2019 (Popova, 2018). Skepticism about Brazil's ineffective role in the union bring the country's struggles in the socio-economic and the political sphere, its status among BRICS members as a "weak" one, as well as the election of Bolsonaro.

2) Brazil staying in the union with no significant changes for BRICS under Bolsonaro's presidency: this scenario case includes predominance of the far-right ideology followed by Bolsonaro and less pragmatism in his actions regarding BRICS (Muhandiram, 2019). Also, a factor that might play a significant role is the complex relationship between Brazil and China, consisting in dissimilarities in political ideologies.

3) Complete disintegration of this partnership, i.e. Brazil's pulling out of BRICS: a "Braxit" development of the events is unlikely, as Brazil is largely dependent on its membership in the union, as well its bilateral relationships with some of its members. It should be examined as a possible outcome, as unpredictability in international affairs is an important feature that needs to be kept in mind.

We have examined the emerging trends in Bolsonaro' foreign policy after his election and can describe its:

1) Prioritizing bilateral relations under Bolsonaro.

The first official trip of Bolsonaro was to the United States on 19 March 2019, only two months after the newly elected president's inauguration. Apart from deepening the economic ties between the two countries, Bolsonaro has taken a pro-US stand towards 
the ongoing crisis in Venezuela; he has decided to open the Brazilian borders for American tourists and strip off the visa regime, as well as giving a promise to move its embassy in Israel from Tel Aviv to Jerusalem (Gonzalez and Leme, 2019). On the other hand, Trump has suggested that Brazil can change its status from a major non-NATO ally to a full member, as well as it offered support for Brazil joining OECD. As close as the relationship between Brazil and the US might seem, two things must be noted. First of all, Bolsonaro will have to make sure that his plans about the future cooperation between the countries materialize with viable benefits for Brazil. That, however, will be a difficult task, as pressure by activists has already emerged in North America in response to the newly formed "friendship". In May, Bolsonaro was due to attend a gala dinner in his honour in New York, organized by the Brazilian-American Chamber of Commerce (Zanini, 2019). Nevertheless, pressure groups consisting of gay rights and environmental campaigners managed to cause a cancellation in the decision to honour Bolsonaro with the person of the year award. The second thing to note is the specific relationship Brazil-USA-China. As much as Brazil might want to repeat the trade wars that the US started with China, that would not be a realistic move. China is a key player for the development of Brazil's economy, however, Bolsonaro has not once shown his dislike of this fact, which might be problematic in future.

The anti-globalist foreign policy rhetoric used by Bolsonaro in his pre-election campaign in 2018 included sharp accusations towards China, which has been dramatically increasing its influence in Brazil in the last few years. That was one of the indicators that the relationship with BRICS might be negatively affected, under Bolsonaro's presidency. However, pressure from diplomats and business leaders "have persuaded Bolsonaro to tone down his anti-China rhetoric" (Glushkova, et al., 2019). A meeting between $\mathrm{Xi}$ and Bolsonaro occurred before the Summit, which was a great way to show that the Brazilian leader evaluates the interdependency of this relationship better. We should note though that the merits for this can hardly be ascribed to Bolsonaro. Vice President Hamilton Mourão was one of the key people who ensured the healing of Brazilian-Chinese relations, after spending the first six months in office on undoing the damage made by the president. Xi Jinping has abstained from answering back to Bolsonaro's attacks, which did not "feed" supporters of this rhetoric in Brazil. What is more, $\mathrm{Xi}$ has tried to earn Brazilian friendship through supporting Brazil in moments when no other country did (regarding Amazon fires in the summer when Bolsonaro was blamed not to have done enough, but Xi publicly praised him instead).

2) Lowering the status of BRICS.

The most significant indicator for Brazil's reluctance to be an active participant in BRICS was the complete absence of discussion from the side of the president regarding the organization of the 11th Summit in the months before November. In Bolsonaro's first three months as a leader of the country the main priorities in domestic policy were pension reform and easing gun ownership, while in his foreign policy the new president dedicated his time to meetings with like-minded country leaders in order to form useful for his agenda political friendships. His ministers and he himself never mentioned BRICS in official speeches and interviews. The new administration was accused of practically making BRICS "nearly invisible" (Spring and Soldatkin, 2019).

\section{3) Cancellation of BRICS Plus meeting.}

Until the election of the new cabinet, cooperation with countries from the South, especially between developing and the least developed countries, has been a consistently implemented part of the foreign affairs of Brazil. However, Bolsonaro has openly criticized this policy, stating that a better way for Brazil to reach an economic growth would be to turn to international partners who perform well, in particular, the USA. According to Bolsonaro's views, "the new Brazil which we are building" should open its currently closed trade and should put a focus on bilateral deals. This is one possible explication of the fact that Bolsonaro cancelled the BRICS Plus meeting (the five members of BRICS meet with neighboring countries of the host) under its chairmanship. Brazil is the only country of the block, which accepts Juan Guaido as acting president, so it would not compromise by inviting Nicolas Maduro. Such a decision, inclined on siding with the USA, also proved to weaken the link with BRICS. Furthermore, the Venezuela issue was not discussed publicly during the Summit in order to avoid confrontation.

\section{SUMMARY}

This research brings value by putting all the assumptions in the current political context, while it analyses their further development, according to the actions taken by Bolsonaro in 2019. We have examined the possible solutions regarding Brazil's 
participation in BRICS after the election of a new farright president: three different options emerged.

Of course, Bolsonaro' foreign policy staying under strong impact of his political ideas, but globalization push Brazil to improve economic relations of with leading developing countries (such as China and India) in the era of expanding global sourcing that can play a critical role as an important factor for developing countries' economies. That is why Bolsonaro cannot ignore BRICS (Penkovtsev, et al., 2017).

At the same time Bolsonaro' relations with USA cannot be non-conflict, because, as known, American foreign policy strategy based on the principle of absolute and global domination of the United States and aimed at maintaining and strengthening the unipolar world. The experience of International relations in XXI century demonstrates that USA has a tend to resort to military force in case of international contradictions (Penkovtsev, et al., 2015). Thus, BRICS can provide the additional opportunities for Brazil in the case of possible contradictions with USA.

\section{CONCLUSIONS}

Based on the results of research and discussion, it can be concluded that competence has a positive and significant effect on performance. According to the questionnaire that was circulated to the SMBs in Brazil Market. The level of employee's competencies affects the performance of employees such as when the employee has knowledge of producing and selling the good, it will increase employee performance. A hypothesis that the union will keep functioning with low enthusiasm from Brazil's side was chosen as the most probable one. Key events from Bolsonaro's presidency in his first year were evaluated, which allows concluding that participation in BRICS does not seem to form a significant part of the foreign policy of Brazil. This predisposes passiveness and low initiative from the side of Latin America's biggest democracy, which hosted the annual summit of BRICS in 2019. However, the anti-globalist rhetoric of Bolsonaro has diminished, as he revaluated the importance of Chinese-Brazilian relations, in particular. It will be useful to continue monitoring the actions of Brazil towards BRICS and follow the 12th Summit, which will be hosted by Russia.

\section{ACKNOWLEDGEMENTS}

The work is performed according to the Russian Government Program of Competitive Growth of Kazan Federal University.

\section{REFERENCES}

Ali AYS, Sidow, MA, and Guleid, HS. 2013. "Leadership styles and job satisfaction: Empirical evidence from Mogadishu universities." European Journal of Management Sciences and Economics, 1 (1): 1-10.

Beach, D., (2012). Process Tracing methods - an introduction. 1st ed. [Electronic source] Denmark: University of Aarhus, $57 \mathrm{p}$. Available https://www.press.umich.edu/resources/Beach Lecture.pdf (Accessed 06.04.2019).

Collier V, D., (2011). Understanding Process Tracing. Political Science and Politics. 44(4), pp. 823-830. https://doi.org/10.1017/S1049096511001429

Escher, F. (2020). Class Dynamics of Rural Transformation in Brazil: A Critical Assessment of the Current Agrarian Debate. Agrarian South: Journal of Political Economy, 9(2), 144-170.

Gallego, E. (2018). How Bolsonaro came to pass. [Electronic source] Rosa Luxemburg Stiftung. Available at: http://www.rosaluxnyc.org/how-bolsonaro-came-to-pass/ 06.04.2019).

(Accessed

Glushkova S, Lomakina O, Sakulyeva T., (20190. The economy of developing countries in the context of globalization: Global supply chain management. International Journal of Supply Chain Management. Volume 8, Issue 1. pp.876-884.

Gonzalez, E. and Leme, L. (2019). Tracking the First 100 Days of Brazilian President Jair Bolsonaro. [Electronic source]. Available at: https://www.as-coa.org/articles/tracking-first100-days-brazilian-president-jair-bolsonaro (Accessed 06.04.2019).

Hammond, A., (2018). Brics seeks to shape New World Order. [Electronic source]. Available at: http://infobrics.org/post/ 27221 (Accessed 06.04.2019).

Hunter, W. and Power, T. (2019). Bolsonaro and Brazil's illiberal backlash. Journal of Democracy, 30(1), pp. 69-82. https://doi.org/10.1353/jod.2019.0005

Mengije, W., (2018). 10 Years on: How has BRICS Performed over the Last Decade? [Electronic source]. Available at: http://infobrics.org/post/27161 (Accessed 06.04.2019).

Muhandiram, N. L., (2019). Future of BRICS: BRAXIT or "Power Next"? [Electronic source]. Available at: http://infobrics.org/post/28277/ (Accessed 06.04.2019).

Penkovtsev R., Nikulshin G., Zinnatullin E., (2017). Strategic priorities in the Foreign Policy course of the USA in the system of Modern International Relations. National Academy of managerial staff of Culture and Arts Herald. Vol., Is.4. pp.227-230.

Penkovtsev R.V, Shibanova N.A., (2015) Wars and military conflicts of the XXI century in the context of the strategic interests of the United States. Journal of Sustainable Development. Volume 8, Issue 4. pp.164-168. https://doi.org/10.5539/jsd.v8n4p164

Popova I.M., (2018) Predsedatel'stvo Brazilii v BRIKS v 2019 g.: chego ozhidat' ot nachala novogo desyatiletiya sotrudnichestva i administratsii Zh. Bolsonaru. Vestnik RUDN. Seriya: Mezhdunarodnye otnosheniya. Vol. 18, No. 4. pp. $925-941$.

https://doi.org/10.22363/2313-0660-2018-18-4-925-941

Presidency of the Republic of Brazil (2019). Bolsonaro makes proposals and strengthens ties with other countries. [Electronic source]. Available at: http://www.brazil.gov.br/ about-brazil/news/2019/01/bolsonaro-make-proposals-andstrengthens-ties-with-other-countries (Accessed 06.04.2019).

Sergunin, A. and Gao, F. (2018). BRICS as the Subject of Study of International Relations Theory. International Organisations Research Journal. 13(4), pp.55-73.

https://doi.org/10.17323/1996-7845-2018-04-03 
Solano, E. (2018). The middle classes hate the Workers' Party. [Electronic source]. International Politics and Society. Available at: https://www.ips-journal.eu/regions/latinamerica/article/show/the-middle-classes-hate-the-workersparty-3013/ (Accessed 06.04.2019).

Spring, J. and Soldatkin, V., (2019). BRICS leaders rail against "bullying" protectionism. [Electronic source]. Available at: https://www.reuters.com/article/us-brics-summit/bricsleaders-rail-against-bullying-protectionism-idUSKBN1XN1YY (Accessed 06.04.2019).

Zanini, F., (2019). BRICS Under New Brazilian President. [Electronic source]. Available at: http://infobrics.org/post/28053 (Accessed 06.04.2019).

(C) 2021 Sakaev and Popova; Licensee Lifescience Global.

This is an open access article licensed under the terms of the Creative Commons Attribution Non-Commercial License (http://creativecommons.org/licenses/by-nc/3.0/) which permits unrestricted, non-commercial use, distribution and reproduction in any medium, provided the work is properly cited. 